\title{
IRRIGATION POND STRATIFICATION STRUCTURE DETERMINATION AND TEMPERATURE - DISSOLVED OXYGEN MODELING USING CE-QUAL-W2
}

\author{
HASANOĞLU, E. ${ }^{1}-$ GÖNCÜ, S. ${ }^{2 *}$ \\ ${ }^{I}$ Department of Environmental Engineering, The Graduate School of Science, Anadolu \\ University \\ Eskisehir, Turkey \\ ${ }^{2}$ Department of Environmental Engineering, Faculty of Engineering, Anadolu University \\ Eskisehir, Turkey \\ *Corresponding author \\ e-mail: sgoncu@anadolu.edu.tr \\ (Received $30^{\text {th }}$ Oct 2017; accepted $12^{\text {th }}$ Feb 2018)
}

\begin{abstract}
Thermal stratification experienced in irrigation ponds leads to intensification of agricultural pollution events due to hypolimnetic oxygen depletion. In this study, stratification in a small pond in western Turkey was investigated. Pond bathymetry was determined with a combination of an Acoustic Doppler Current Profiler (ADCP) equipment measurement and field study using Real Time Kinematic GPS (RTK GPS) equipment. The Relative Thermal Resistance to Mixing (RTRM) index and 2dimensional hydrologic model CE-QUAL-W2 was utilized to characterize the stratification structure. Based on these monitoring results, the temperature profile was constructed. The pond volume was found to be occupied by $60 \%$ with the epilimnion, $20 \%$ metalimnion and $20 \%$ hypolimnion. The model was calibrated with monitoring data from 2013 and validated with data from 2014. It was determined that the pond was monomictic. The pond was modeled with CE-QUAL-W2 and the dates of stratification, the temperature and dissolved oxygen profiles were simulated with absolute mean errors of $0.77{ }^{\circ} \mathrm{C}$ for temperature and $1.09 \mathrm{mgO}_{2} / \mathrm{L}$ for dissolved oxygen. Different irrigation and meteorological scenarios were examined to predict pond volumes and temperatures till 2020. As a result of scenario implementations, drip irrigation practices were found to be the best management application for the sustainable management of the pond.
\end{abstract}

Keywords: $2 D$ modeling, relative thermal resistance to mixing (RTRM), thermal stratification, forecasting, scenario implementation

\section{Introduction}

Temperature is one of the most important physical property of water bodies as it affects density, vapor pressure, viscosity, dissolved oxygen concentration and chemical and biological reaction kinetics. Heating of natural bodies by solar radiation and atmospheric temperatures from the surface down to the deeper parts results in different water densities at different depths and hence to thermal stratification (Chapra, 1997). Stratification can affect many important water quality parameters adversely, foremost the dissolved oxygen. Stratification prevents the transfer of oxygen to the hypolimnion layer. Moreover, due to anoxic conditions prevailing in the deeper layers, the solubility of phosphorus and iron increase and especially phosphorus is released to the water column in overturning periods, thus leading to algal blooms (Salonen et al., 1999). Decreased oxygen levels due to stratification also affect fish populations and diversity adversely. Therefore, stratification is a phenomenon that needs careful consideration in the study of standing water bodies. 
There are several studies concerning stratification in water bodies which are directed to different aims using a variety of methods. A major portion of these studies is related to the determination of the stratification structure, its evolution and assessment (Birge, 1910; Kindle, 1929; Lap et al., 2009). Some studies are concerned with the relationship of the geological properties of the region with stratification (Chapman et al., 1998). Other deal with the effects of surface heat exchange and wind parameters on stratification (Churchill and Kerfoot, 2007). Studies about the timing of stratification and the determination of the lake number which is used to identity the different layers are also widespread (Elci, 2008; Song et al., 2013; Branco and Torgersen, 2009). In Turkey, there are studies about the relationship of stratification with water quality parameters (Elci, 2008; Gunduz et al., 1998; Erturk et al., 2008; Caliskan and Elci, 2009; Alpaslan et al., 2012). Reservoirs are multi-purpose deep waterbodies and water temperature and dissolved oxygen status are very important. Due to improper practices, climate change effects and drought conditions may result in reduced hypolimnetic volumes, anoxic conditions and algal blooms. (Hudson and Vandergucht, 2015). Zhang et al. (2015) stated that dissolved oxygen profiles are directly linked with the water temperature depth profiles in reservoirs. Also increases in the daily mean air temperatures may cause a decrease of the oxycline depth, respectively expediting oxygen stratification and diminishing water quality.

The literature also contains studies concerning the modeling of stratification coupled with water quality. The foundation for such studies were one-dimensional models of stratification (Babajimopoulos and Papadopoulos, 1986; Rice et al., 1989; Bell et al., 2006; Spigel et al., 2005; Dueri et al., 2009). 2-D mathematical models were employed to more accurately represent the thermal stratification structure. 3-D models based on 3D hydrodynamical formulations were also attempted (Hassan et al., 1998; Li et al., 2010; Bocaniov et al., 2014). Because reservoirs usually have a deep water column, thermal stratification and dissolved oxygen conditions are more common than in shallow lakes. For this reason, reservoir thermal and oxygen stratification structures were modeled in different studies (Kuo et al., 2006; Bonnet and Poulin, 2004; Lindim et al., 2011; Kerimoglu and Rinke, 2013)

Studies conducted using CE-QUAL-W2 are widespread in literature. Cole (2000) reviewed temperature models of reservoirs with CE-QUAL-W2 and presented results of these studies. Besides modeling temperature and water quality parameters, they also created several scenarios on how to increase the trophic status of the reservoir from eutrophic to oligotrophic. Berger et al. (2005) modeled temperature in Lake Laurance and presented aspects of hydrodynamical and temperature calibration. They also created scenarios to determine how the outflow temperatures changed accordingly. Kim and Kim (2006) modeled temperature changes in Lake Soyang with CE-QUAL-W2 model. Data from 1996 was used for calibration and data from the 1995-2005 period for validation. Kuo et al. (2006) repeated their studies for the Te-Chi ve Tseng-Wen reservoirs with CE-QUAL-W2 to improve the trophic status. Williams (2007) modeled Lake Powell with CE-QUAL-W2 water temperature and water quality parameters. Stansbury et al. (2008) modeled Lake Ogallala with respect to dissolved oxygen again with CE-QUAL-W2 to determine its sources and consumes. Batick (2011) reviewed the general features of the model, its development and input parameters, using it for the modeling of the Cheatham Reservoir temperature and dissolved oxygen profiles.

The aim of this study is to investigate the stratification structure of a relatively clean surface water body (Borabey Pond) and to determine how dissolved oxygen 
concentrations change spatially within the water body. The CE-QUAL-W2 model was implemented, with the meteorological conditions an inflow and outflow quantities as driving forces, to characterize mass transfer in the ponds thermal stratification structure and modeling of the dissolved oxygen concentration. Furthermore, scenarios were developed to forecast how the pond temperature will behave in the future in response to changing pond volumes as a result of management practices and climatic influences.

\section{Study site}

The Borabey Pond is situated to the north of Eskişehir, in Northwestern Inner Anatolia, Turkey. It is located in the foothills of the Bozdağ mountain at an altitude of $924 \mathrm{~m}$ (the maximum water level of the pond). The earthen dam of the reservoir was constructed in 1991-1992 to serve irrigation needs of a $2.48 \mathrm{~km}^{2}$ farming area (Hasanoğlu, 2012). The location of the pond is given in Figure 1.

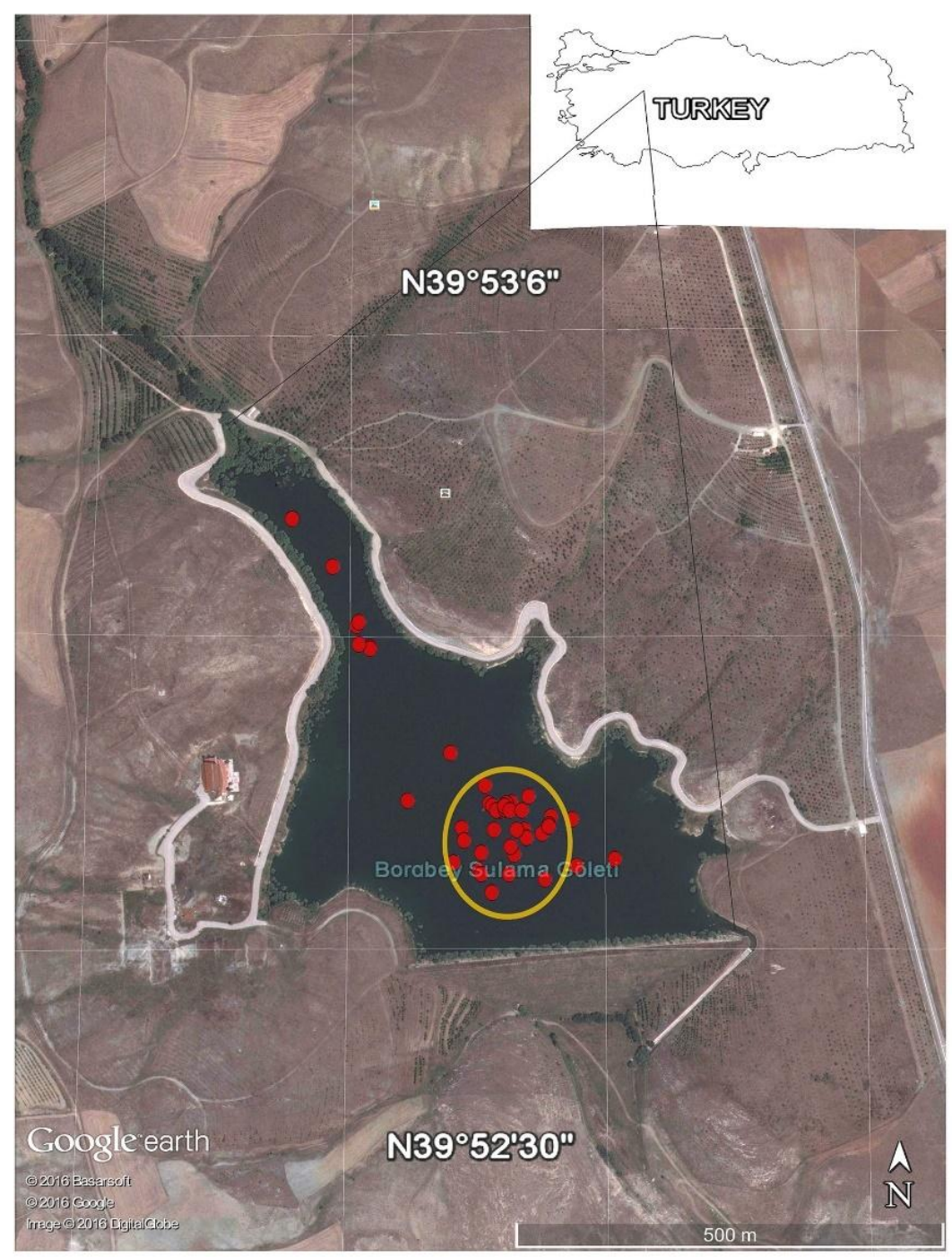

Figure 1. Borabey Pond location in Turkey and measurement locations (red dots) during in 2013 and 2014 
The watershed area is $8583 \mathrm{~km}^{2}$. The pond is $200 \mathrm{~m}$ wide and $620 \mathrm{~m}$ long on average with a maximum width of $350 \mathrm{~m}$. The mean depth is $8.5 \mathrm{~m}$ with a maximum value of $18.8 \mathrm{~m}$. The water level of the pond shows fluctuations due to changes in water inputs and irrigation withdrawals. The minimum talveg elevation is $906 \mathrm{~m}$ above mean sea level and the maximum water level is held fixed at $924 \mathrm{~m}$ via an outlet weir at this elevation. The water source feeding the pond is a small creek which carries water in the rainy season and dries up in summer. A pipe at $906.62 \mathrm{~m}$ within the pond near the dam is used to release irrigation water to ditches downstream. The volume of the pond at maximum level amounts to 1.6 million $\mathrm{m}^{3}$.

\section{Materials and methods}

\section{Meteorological and limnological observations}

The modeling period was chosen as the years of 2013 and 2014 and meteorological data related to this period was obtained from a weather station (Davis Vantage Pro 2) located at the shore of the pond. The meteorological time series at 15-min intervals comprise of air temperature, dew point temperature, wind velocity, wind direction, precipitation amount and solar radiation. Precipitation ranged within this period from a low of $2 \mathrm{~mm}$ in July 2013 to a high of $97 \mathrm{~mm}$ in October 2013. Temperatures changed between $-10.8{ }^{\circ} \mathrm{C}$ in December 2013 to $36.1{ }^{\circ} \mathrm{C}$ in August 2014. Due to the presence of missing values in February 2013, the model was run beginning in the $56^{\text {th }}$ day of 2013.

The pond stratifies in summer and overturns in spring and fall. In this respect the pond is a monomictic water body. The epilimnion occurs at a mean depth of $7 \mathrm{~m}$. Periodic water temperature and dissolved oxygen measurements were conducted in the Borabey Pond to determine the stratification structure and to calibrate and validate the CE-QUAL-W2 model. The vertical temperature profile was determined with the vertical profiler (Casaway-CTD) equipment while the dissolved oxygen measurements were conducted using multi parameter meter (HACH HQ40d) with a LOD probe. The measurements were taken at $1 \mathrm{~m}$ depth intervals and 46 temperature and 41 dissolved oxygen profiles were generated. The measurements were primarily concentrated in the deeper zones of the pond.

Statistics about temperature, dissolved oxygen measurements and water density results as derived from measurements are displayed in Table 1. The locations of the measurement points are shown in Figure 1.

The bathymetry of the pond was determined with Sontek M9 Aqoustic Doppler Current Profiler. Because the pond shows varying densities along the depth, a correction for this feature was applied using density results from Castaway CTD observations (Göncü et al., 2014). The resulting bathymetric map is presented in Figure 2. The measurements were processed with ArcGIS 10 to create the contours in Figure 2. ArcGIS was also employed to determine the surface area and volume of the pond at various depths.

The watershed of the pond is shown in Figure 3 with the subwatersheds. The areas and other relevant data were provided by the ArcGIS software and ArcHydro module. Subwatershed No.1 did not feed the pond in the 2013-2014 period as its waters were derived to another pond nearby. Subwatersheds No.2 and No.3 also could not feed the pond as the creeks emptying them were diverted for irrigation purposes. Thus, within the simulation period only the remaining $3.24 \mathrm{~km}^{2}$ of the watershed provided the pond with water. 
Table 1. Descriptive statistics about dissolved oxygen, temperature observations and derived water density results

\begin{tabular}{c|c|c|c}
\hline \multicolumn{4}{c}{ Observation start date: $\mathbf{2 6 . 0 2 . 2 0 1 3}$} \\
\hline \multirow{4}{*}{ Observation end date: 25.11.2014 } \\
\hline n & $\begin{array}{c}\text { Dissolved oxygen } \\
\text { mg/L }\end{array}$ & $\begin{array}{c}\text { Temperature } \\
{ }^{\circ} \mathbf{C}\end{array}$ & $\begin{array}{c}\text { Density } \\
\mathbf{k g} / \mathbf{m}^{\mathbf{3}}\end{array}$ \\
\hline Min & 556 & 1757 & 601 \\
P10 & 0.05 & 2.58 & 997.48 \\
P25 & 0.25 & 6.29 & 997.99 \\
P50 & 4.63 & 8.80 & 998.83 \\
P75 & 7.83 & 12.29 & 999.77 \\
P90 & 9.39 & 18.68 & 1000.08 \\
Max & 11.07 & 21.87 & 1000.15 \\
Std. dev. & 11.92 & 23.93 & 1008.45 \\
\hline
\end{tabular}

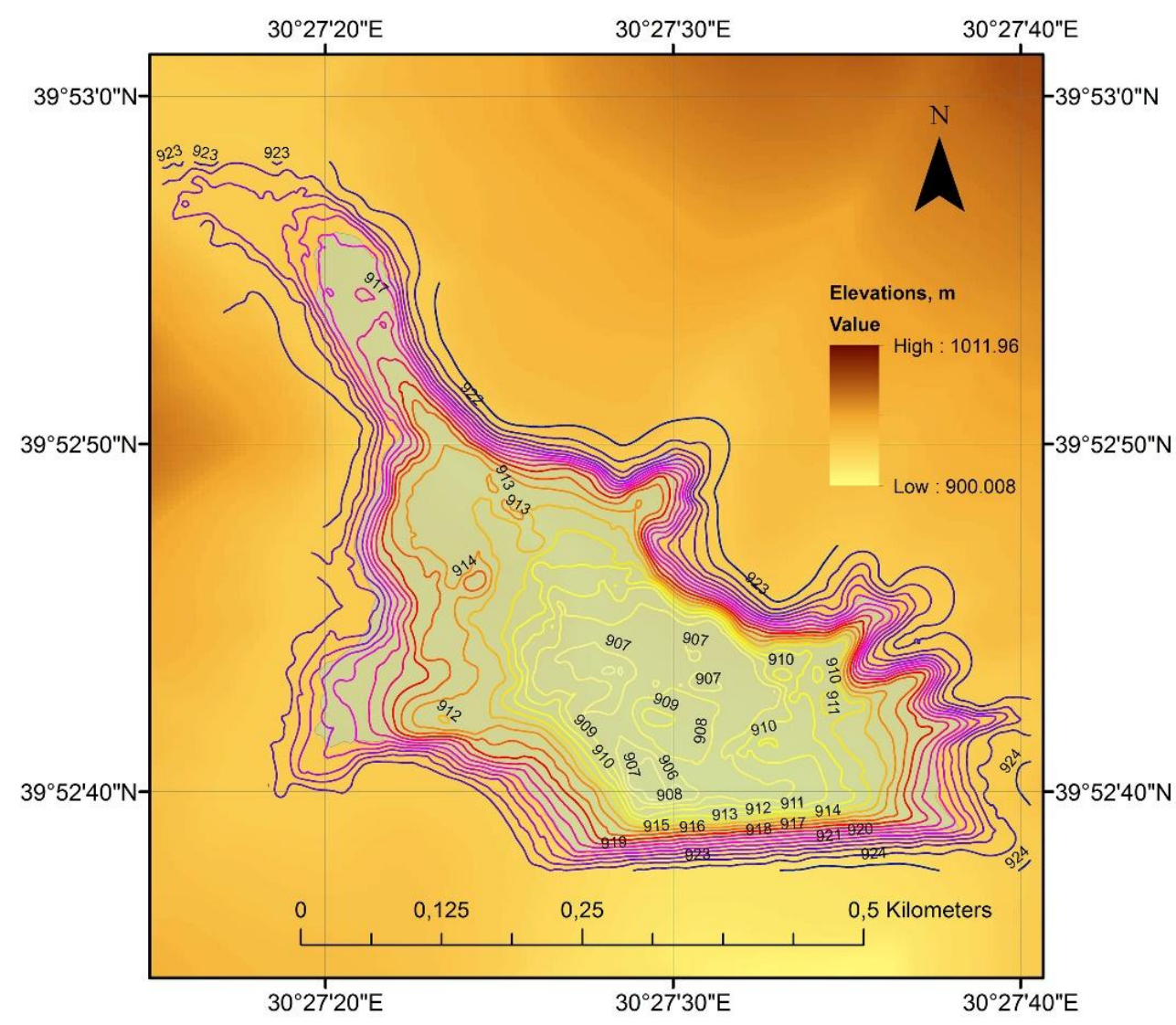

Figure 2. Borabey Pond bathymetric map 


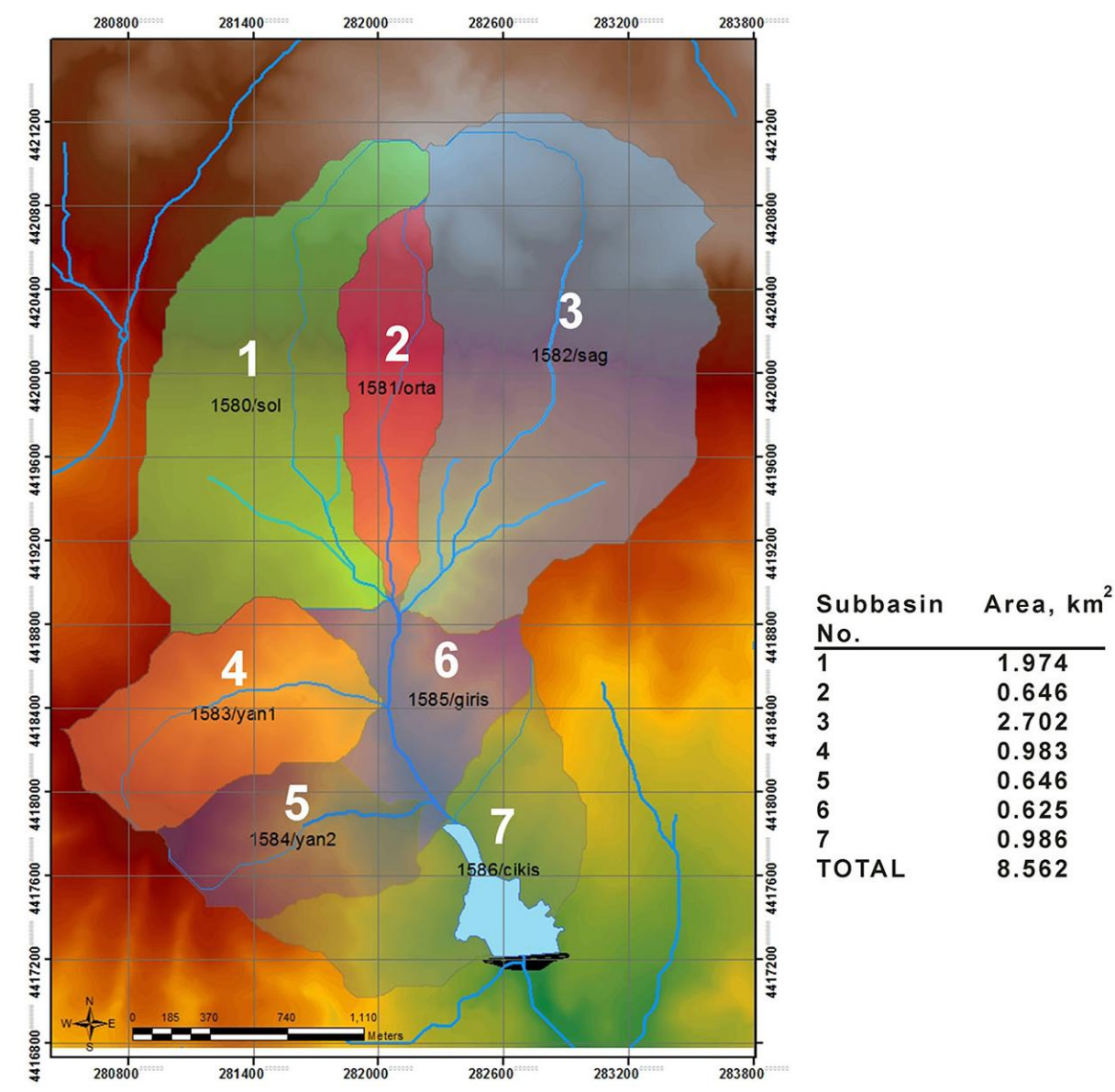

Figure 3. Borabey Pond watershed and subwatersheds

\section{Determination of RTRM index}

The strength of the thermal stratification is obtained from the RTRM (Relative Thermal Resistance to Mixing) index which is determined for consecutive depths. This index was first introduced by Birge (1910). Becker et al. (2009), Branco et al. (2009) and Alpaslan et al. (2012) named the index RWCS (Relative Water Column Stability) and used it as such.

The index is determined by Equation 1 (Chimney et al., 2006).

$$
\psi=\frac{\rho_{z 2}-\rho_{z 1}}{\rho_{4}-\rho_{5}}
$$

$\Psi$ stands for the RTRM index and is a dimensionless quantity. $\rho z_{1}$ and $\rho z_{2}$ are the water densities at the respective depths $z_{1}$ and $z_{2}$ and are given in $\mathrm{kg} / \mathrm{m}^{3} . \rho_{4}$ and $\rho_{5}$ are the water densities at 4 and $5{ }^{\circ} \mathrm{C}$, respectively (Chimney et al., 2006). The index is determined at $1-\mathrm{m}$ intervals. Values larger them 20 generally indicate the upper and lower boundaries of the metalimnion. A cumulative RTRM index indicates the total resistance of the thermal stratification to mixing (Kortmann et al., 1982).

Figure 4 displays the cumulative RTRM values at the deepest zone of the Borabey Pond at monthly intervals during the 2013-2014 period calculated from density 
observations made by Castaway CTD. The figure displays clearly the monomictic stratification pattern. The volumes of the epilimnion, metalimnion and hypolimnion during stratification as obtained from the bathymetric calculations.

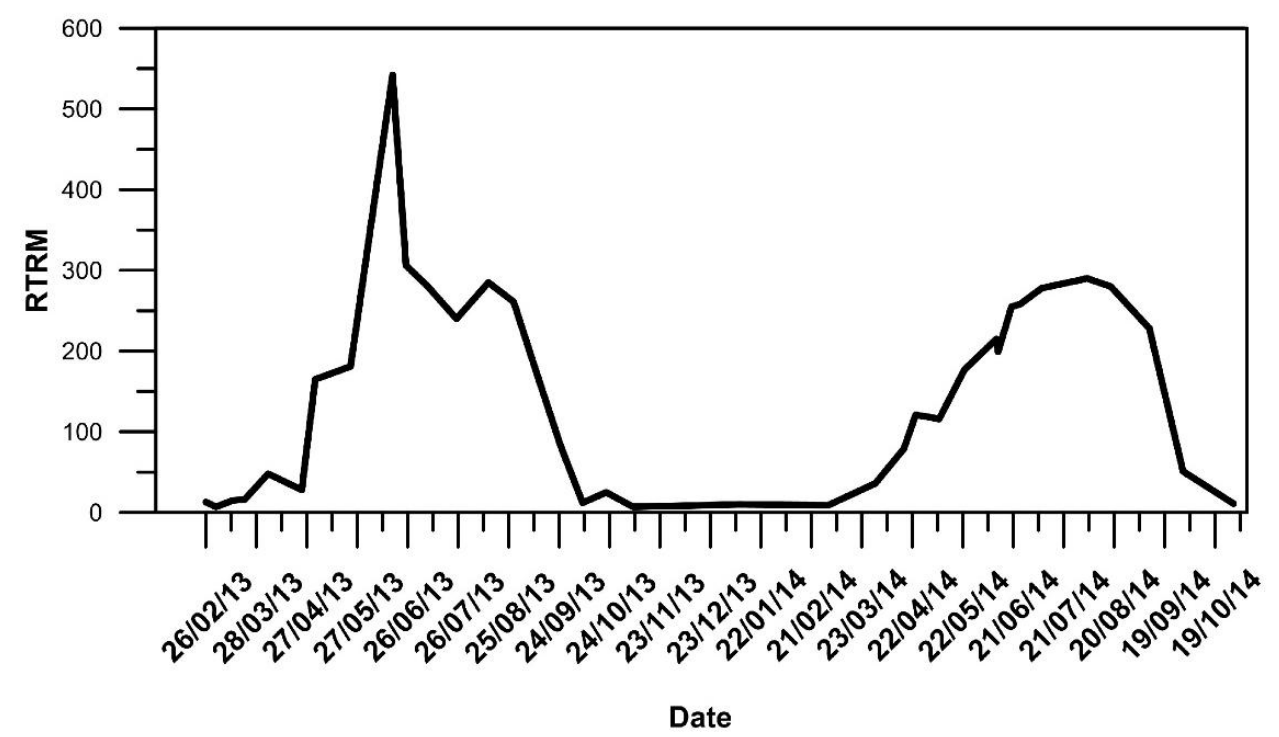

Figure 4. Borabey Pond RTRM profile

\section{Dissolved oxygen and temperature modeling}

CE-QUAL-W2 is a 2-D (in the longitudinal and vertical dimensions) hydrodynamical and water quality model. As it inherently assumes homogeneous longitudinal cross-sections, it is more appropriate for long and narrow water bodies. The model can be applied to streams, lakes, watersheds, estuaries and combinations of these systems (Cole and Wells, 2013).

The CE-QUAL-W2 model can estimate water elevations, velocities, temperatures and water quality concentrations. Quality constituents can be added or removed from the model and combinations can also be handled. The model manages complex systems comprising of different stream branches. The minimum data requirements are bathymetry, inflows and outflows, meteorological time series and initial conditions (Batick, 2011).

Temperature, as it is a primary factor for hydrodynamical and water quality simulations, is required and cannot be left out. Water quality constituents include inorganic solids, phytoplankton and epiphyton groups, CBOD, organic and nutrients like phosphorus and nitrogen species (Batick, 2011). The model was tested in many reservoirs for its capability of adequately representing the thermal stratification pattern and simulating water quality and is widely used today (Cole and Tillman, 1999; Deliman and Gerald, 2002; Bowen and Hieronymus, 2003; Colarusso et al., 2003; Kim and Kim, 2006; Ha and Lee, 2007; Diogo et al., 2008; Zhang et al., 2008; Bonalumi et al., 2012).

From the bathymetric data of the Borabey Pond the grid structure was obtained with the use of the ArcGIS software. The finite difference grid structure is displayed in Figure 5. Six segments were distinguished in the longitudinal direction with the corresponding number of layers. Using the elevation-surface, area-volume relationships, 
the average width of every layer was obtained. A total of 80 layers each with a uniform depth of $1 \mathrm{~m}$ was created and the correspondence of the grid structure with the actual bathymetry was tested with the Nash-Sutcliffe efficiency index (NSE). An index of 0.99 was obtained for surface areas and 0.97 for volumes, thus indicating a very good grid representation of the bathymetry.


Figure 5. The finite difference grid structure of the Borabey Pond bathymetry

Therefore, inflow water quantities were estimated by comparing the watershed area with the watershed area of a $5 \mathrm{~km}$ distant pond (The Keskin Pond) which shows similar hydrological characteristics. So discharge values obtained for the Keskin Pond were transferred to the Borabey Pond by the method of watershed drainage-area ratios (Dayyani et al., 2003). So, for the year of 2013 and 2014, derived flow values were constructed. The actual flow values for 2013 for the Borabey Pond were found to be in good agreement with the corresponding derived flow values.

For the outflow quantities form the pond, the irrigation withdrawals were used. The irrigation withdrawal quantities were not of daily resolution. To refine the resolution to daily values, the crop patterns downstream of the pond were compared to the patterns in the region and correlations were established between the amounts of water used for irrigation in the region and regional crop patterns to be used to estimate the daily amount withdrawn from the pond taking into consideration the watershed areal differences, too.

As the input creek temperatures, the water temperatures measured at the place where the creek enter the lake were utilized. From the temperature profiles obtained by the CASTAWAY CDT profiler equipment, spline smoothing was used to find daily temperatures. As the outlet water temperature, the temperature obtained from the profiles at the depth of the outlet structure were utilized.

The water levels in the pond were measured at discrete times at a water level gage during the 2013 and 2014 period. The interpolation to daily values was obtained by Akima Spline Interpolation with the HydroClimATe software.

All meteorological time series (air temperature, dew point temperature, wind velocity, wind direction, precipitation and solar radiation) were obtained from the station at the pond with the exception of cloudiness for which the time series were obtained from the Eskisehir Anadolu Airport Meteorological Station LTBY which is 9 $\mathrm{km}$ distant to the Borabey Pond.

Kaya (2013) measured, on a monthly basis, water quality parameters at the pond. These included phosphate, ammonia, nitrite and nitrate. Algae concentrations were calculated from Chlorophyll-a with a numerical approach. Labile and refractory dissolved organic matter (L-DOM and R-DOM) and labile and refractory particulate organic matter (L-POM and R-POM) were obtained from total organic carbon and algae 
concentrations (Cole and Tillman, 1999). February 26, 2013 was fixed as the starting day of simulations and 15-min intervals were used in correspondence with meteorological time series intervals.

\section{Model calibration and validation}

Data in the simulation year 2013 were used for calibration and data in 2014 for validation. In the calibration of CE-QUAL-W2 model the water elevation is a key parameter as it affects all the subsequent calculations. Therefore, the agreement between observed and simulated water level is checked first. The levels are calibrated by incrementally increasing or decreasing the input volumes (Devonis, 2011). The initial agreement is displayed in Figure 6. The disagreement in 2014 was corrected with calibration. The water level observations were obtained from readings at an established gauging station in the pond. An NSE index of 0.97 was obtained after calibration.

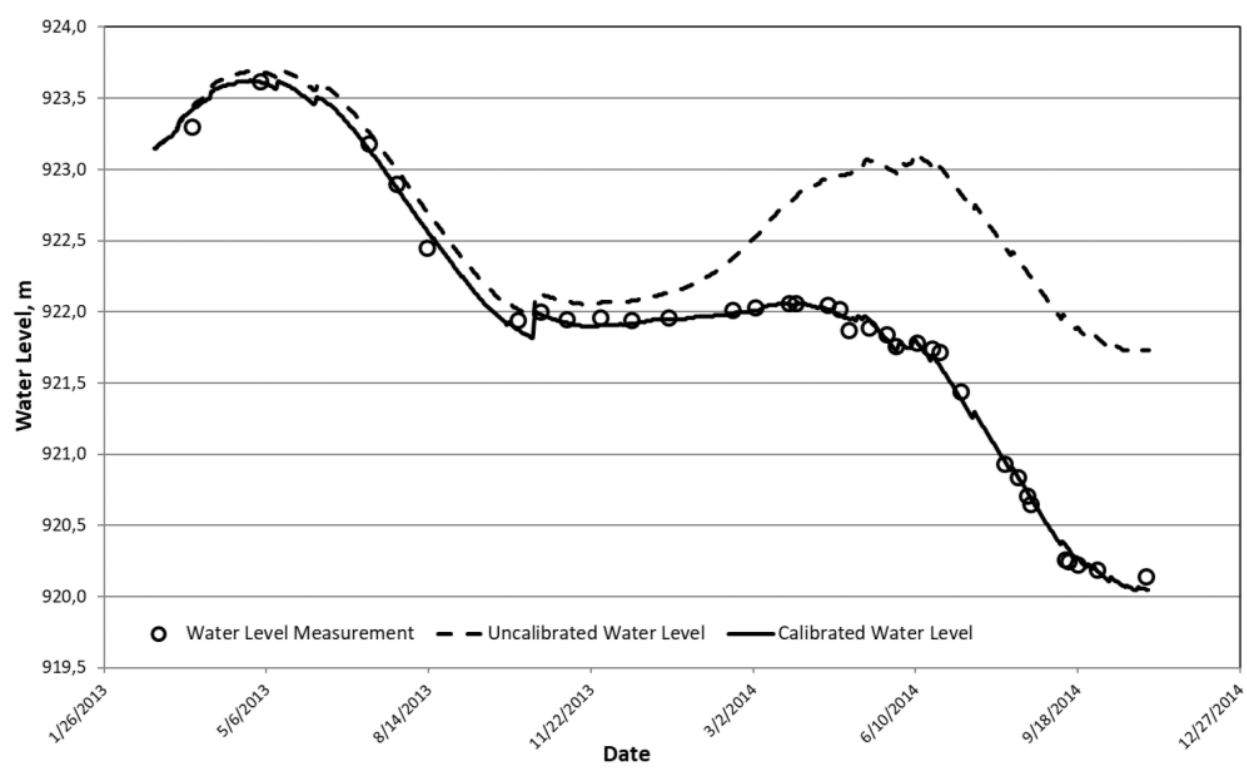

Figure 6. The Borabey Pond water level with and without calibration between 2013 and 2014

For the calibration of temperature, a sensitivity analysis for 8 parameters was conducted. Default values were used as initial values and these were varied by $\pm 5 \%$, $\pm 10 \%$ and $\pm 15 \%$. The model was thus run 56 times and absolute mean errors were calculated between modeled and observed temperatures. Table 2 displays the results of the sensitivity runs. From these, it was found that the most sensitive parameters were EXH2O, BETA, AFW, BFW and CFW as Table 3. The model was calibrated using these parameters.

The change of solar radiation with depth is given in Equation 2:

$$
H_{s}(z)=(1-\beta) H_{0} e^{-\eta z}
$$

Here $H_{s}(z)$ is the solar radiation at depth $z, \beta$ the ratio of radiation absorbed by the water surface (BETA in CE-QUAL-W2), $\mathrm{H}_{0}$ the incident radiation on the surface and $\eta$ 
the light extinction coefficient (EXH2O). As BETA and EXH2O affect the heat transfer in water bodies, they were calibrated together.

Table 2. Sensitivity analysis results for temperature calibration parameters

\begin{tabular}{|c|c|c|c|c|c|c|c|c|c|c|}
\hline Variable & Description & Unit & & $-15 \%$ & $-10 \%$ & $-5 \%$ & \begin{tabular}{|l|}
$\begin{array}{l}\text { Initial } \\
\text { value }\end{array}$ \\
\end{tabular} & $+5 \%$ & $+10 \%$ & $+15 \%$ \\
\hline \multirow{2}{*}{ BETA } & \multirow{2}{*}{\begin{tabular}{|c|} 
Solar \\
radiation \\
absorbed in \\
surface layer \\
\end{tabular}} & & Value & 0.38 & 0.41 & 0.43 & 0.45 & 0.47 & 0.50 & 0.52 \\
\hline & & & AME & 0.68 & 0.69 & 0.70 & 0.70 & 0.71 & 0.74 & 0.76 \\
\hline \multirow{2}{*}{ EXH2O } & \multirow{2}{*}{$\begin{array}{c}\text { Extinction } \\
\text { coefficient for } \\
\text { pure water }\end{array}$} & \multirow{2}{*}{$\mathrm{m}^{-1}$} & Value & 0.38 & 0.41 & 0.43 & 0.45 & 0.47 & 0.50 & 0.52 \\
\hline & & & AME & 0.72 & 0.69 & 0.69 & 0.70 & 0.73 & 0.78 & 0.82 \\
\hline \multirow{2}{*}{$\mathbf{A X}$} & \multirow{2}{*}{$\begin{array}{c}\text { Longitudinal } \\
\text { eddy viscosity }\end{array}$} & \multirow{2}{*}{$\mathrm{m}^{2} \mathrm{~s}^{-1}$} & Value & 0.0327 & 0.0347 & 0.0366 & 0.0385 & 0.0404 & 0.0424 & 0.0443 \\
\hline & & & AME & 0.70 & 0.70 & 0.70 & 0.70 & 0.70 & 0.70 & 0.70 \\
\hline \multirow{2}{*}{ DX } & \multirow{2}{*}{$\begin{array}{l}\text { Longitudinal } \\
\text { eddy } \\
\text { diffusivity }\end{array}$} & \multirow{2}{*}{$\mathrm{m}^{2} \mathrm{~s}^{-1}$} & Value & 0.0327 & 0.0347 & 0.0366 & 0.0385 & 0.0404 & 0.0424 & 0.0443 \\
\hline & & & AME & 0.70 & 0.70 & 0.70 & 0.70 & 0.70 & 0.70 & 0.70 \\
\hline \multirow{2}{*}{ CBHE } & \multirow{2}{*}{$\begin{array}{c}\text { Sediment heat } \\
\text { exchange } \\
\text { coefficient }\end{array}$} & \multirow{2}{*}{$\mathrm{Wm}^{-2} \mathrm{~s}^{-1}$} & Value & 0.26 & 0.27 & 0.29 & 0.30 & 0.32 & 0.33 & 0.35 \\
\hline & & & AME & 0.71 & 0.70 & 0.70 & 0.70 & 0.70 & 0.70 & 0.70 \\
\hline \multirow[b]{2}{*}{ AFW } & \multirow{2}{*}{$\begin{array}{l}\text { a coefficient } \\
\text { in the wind } \\
\text { speed } \\
\text { formulation } \\
\end{array}$} & \multirow[b]{2}{*}{$\mathrm{Wm}^{-2} \mathrm{mmHg}^{-1}$} & Value & 7.82 & 8.28 & 8.74 & 9.20 & 9.66 & 10.12 & 10.58 \\
\hline & & & AME & 0.70 & 0.68 & 0.68 & 0.70 & 0.74 & 0.79 & 0.85 \\
\hline \multirow{2}{*}{ BFW } & \multirow{2}{*}{$\begin{array}{c}\mathrm{b} \text { coefficient } \\
\text { in the wind } \\
\text { speed } \\
\text { formulation }\end{array}$} & \multirow{2}{*}{$\begin{array}{c}\mathrm{Wm}^{-2} \mathrm{mmHg}^{-} \\
1\left(\mathrm{~ms}^{-1}\right) \text {-cfw }\end{array}$} & Value & 0.39 & 0.41 & 0.44 & 0.46 & 0.48 & 0.51 & 0.53 \\
\hline & & & AME & 0.68 & 0.69 & 0.69 & 0.70 & 0.71 & 0.73 & 0.74 \\
\hline \multirow{2}{*}{ CFW } & \multirow{2}{*}{$\begin{array}{c}\text { c coefficient } \\
\text { in the wind } \\
\text { speed } \\
\text { formulation }\end{array}$} & & Value & 1.70 & 1.80 & 1.90 & 2.00 & 2.10 & 2.20 & 2.30 \\
\hline & & & AME & 0.68 & 0.68 & 0.68 & 0.70 & 0.74 & 0.80 & 0.89 \\
\hline
\end{tabular}

Table 3. Effects of parameter perturbation on model

\begin{tabular}{c|c|c|c}
\hline & \multicolumn{3}{|c}{ Parameter perturbation } \\
\hline & $\pm 5 \%$ & $\pm 10 \%$ & $\pm 15 \%$ \\
\hline BETA & 0.71 & 3.57 & 5.71 \\
\hline EXH2O & 2.86 & 6.43 & 7.14 \\
\hline AX & 0.00 & 0.00 & 0.00 \\
\hline DX & 0.00 & 0.00 & 0.00 \\
\hline CBHE & 0.00 & 0.00 & -0.71 \\
\hline AFW & 4.29 & 7.86 & 10.71 \\
\hline BFW & 1.43 & 2.86 & 4.29 \\
\hline CFW & 4.29 & 8.57 & 15.00 \\
\hline
\end{tabular}


During calibration, EXH2O and BETA were varied concurrently and the least AME was observed at an EXH2O value of $0.49 \mathrm{~m}^{-1}$ and a BETA value of 0.29. AME was reduced from $0.70{ }^{\circ} \mathrm{C}$ to $0.68{ }^{\circ} \mathrm{C}$ in this process. It was observed that BETA and EXH2O reduced AME while the others increased it. In literature an AME range of 0.3$0.9^{\circ} \mathrm{C}$ is considered an adequate range and when the calibration was stopped the AME was within this range and thus deemed adequate (Cole, 2000).

In dissolved oxygen calibration, the first step is the determination of sediment oxygen demand (SOD) which varies between 0.1-1 $\mathrm{gO}_{2} / \mathrm{m}^{2}$.day (Cole and Wells, 2013). The zero ${ }^{\text {th }}$ order SOD reaction rate was calibrated as $1 \mathrm{gO}_{2} / \mathrm{m}^{2}$.day which gives the minimum AME. This value lead to an AME of $1.12 \mathrm{mgO}_{2} / \mathrm{L}$ in observation and simulation comparisons.

There are different equations in the CE_QUAL-W2 manual which can be used to calculate the relationship of the oxygen reaeration with wind velocity (Cole and Wells, 2013). These equations were tried and the equation which gives the minimum AME value $\left(1.18 \mathrm{mgO}_{2} / \mathrm{L}\right)$ was chosen. In literature, $\mathrm{AME}$ values ranged between 0.58 and $1.25 \mathrm{mgO}_{2} / \mathrm{L}$. Thus the AME was deemed to be adequate. After calibration, the model was run for the complete 2013-2014 period and the results for 2014 were used for validation.

The validation results for 2014 show an AME of $0.86{ }^{\circ} \mathrm{C}$ for temperature and 1.18 $\mathrm{mgO}_{2} / \mathrm{L}$ for dissolved oxygen. When the two-year period was considered, the AME for temperature dropped to $0.77^{\circ} \mathrm{C}$ and $1.09 \mathrm{mgO}_{2} / \mathrm{L}$ for dissolved oxygen.

\section{Results and discussion}

The comparison of model results and observations for temperature profiles at the sixth segment are displayed in Figure 7. As the correspondence of the two curves in each profile shows, the model is capable of adequately representing the beginning and ending times of stratification and the vertical profiles.


Figure 7. Observation and model results for temperature 
The thermocline in the summer stratification begins, on the average, at $6 \mathrm{~m}$ below water surface and reaches around $10 \mathrm{~m}$. The change in water temperature in this region amounts to $5{ }^{\circ} \mathrm{C}$. The fall overturn is observed at the end of September (Figs. 7 and 8).

The temperature profile also affects the distribution of the water quality constituents in the water body. Due to the inhibition of oxygen transfer from the atmosphere by the onset of stratification, the dissolved oxygen levels in the hypolimnion begin to decrease, enhanced by oxidation of organic matter and nitrification.

Figure 8 shows the comparison of the vertical temperature profiles of both simulation and observations. Figure 9 displays the same for dissolved oxygen. As the figure implies, very low dissolved oxygen levels occur during stratification periods, as expected, while in between (in the mixing period between fall 2013 and spring 2014) the oxygen levels do not change appreciably in the vertical direction.

When the temperature and dissolved oxygen observations, calculated RTRM values and model simulations are considered together, it is seen that the stratification sets on at the end of April 2013 and continues till the end of August. In 2014 it begins in mid April and ends likewise at the end of August. According to the RTRM results, the total resistance to mixing is higher in 2013 than in 2014.

The absolute mean error (AME) between the temperature and dissolved oxygen observations and modeled results obtained by the modeling study of the Borabey Pond using the CE-QUAL-W2 model is on the average $0.77{ }^{\circ} \mathrm{C}$ for temperature and 1.09 $\mathrm{mgO}_{2} / \mathrm{L}$ for dissolved oxygen. These are reasonable values as indicated in literature where ranges for temperature and dissolved oxygen are between $0.4-0.9{ }^{\circ} \mathrm{C}$ and 0.55 $1.25 \mathrm{mgO}_{2} / \mathrm{L}$, respectively (Cole and Wells, 2013).

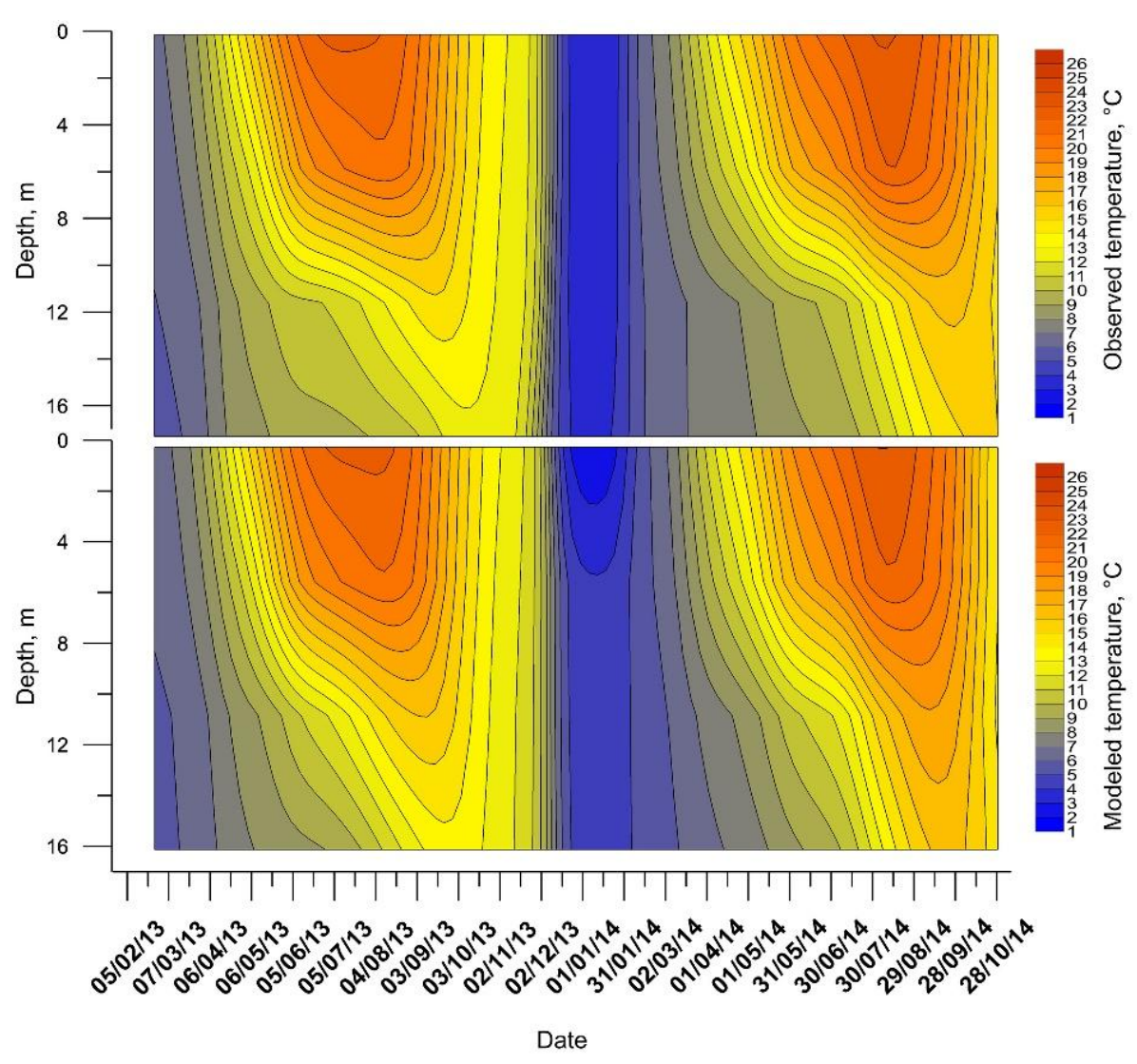

Figure 8. Temperature isopleths according to time (observation and model results) 


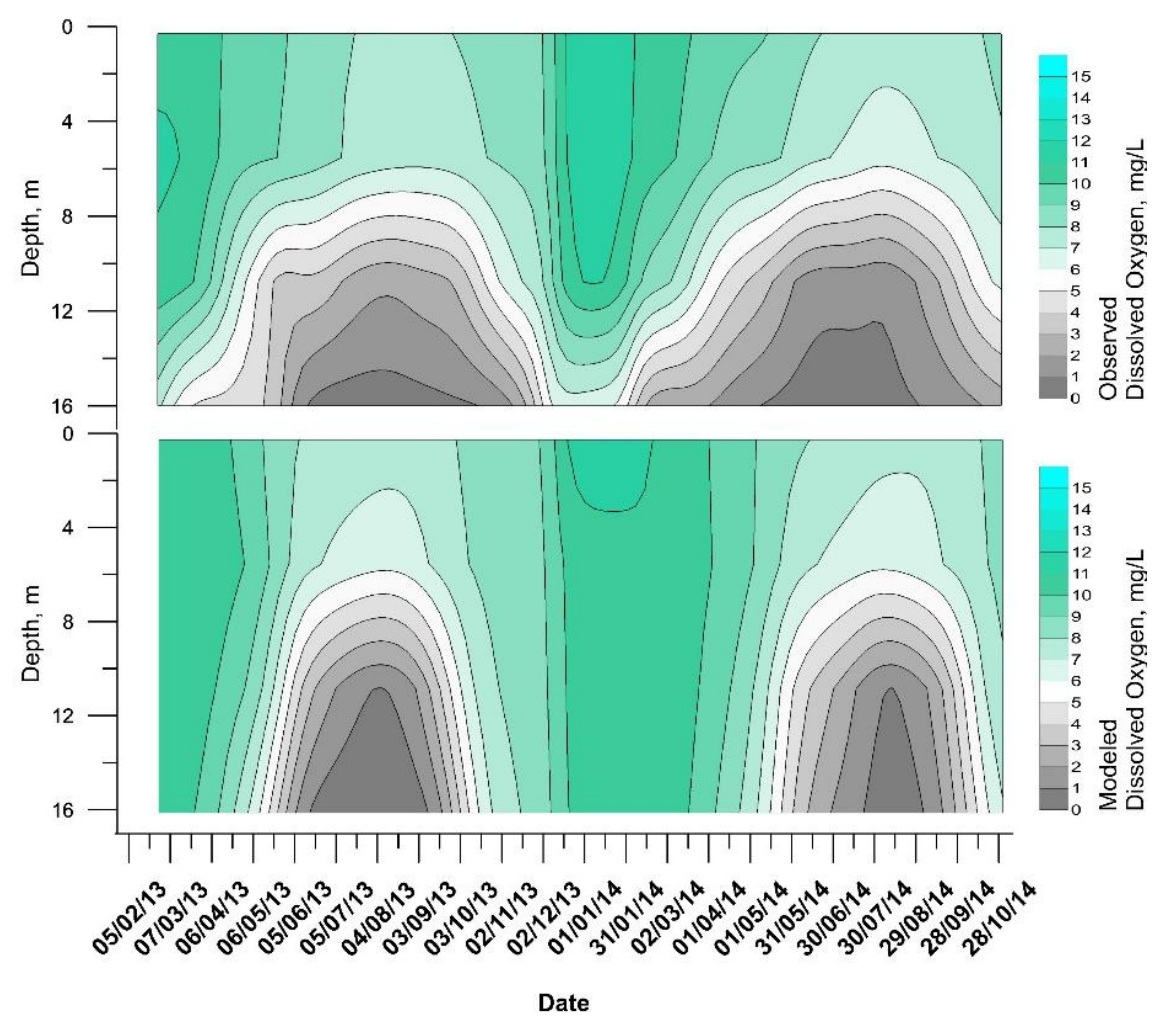

Figure 9. Dissolved oxygen isopleths according to time (observation and model results)

When the observations and simulations were compared for temperature, it was seen that CE-QUAL-W2 modeled the temperature profiles quite consistently together with the beginning and ending dates of stratification. For dissolved oxygen, the observations and simulations agreed especially during the stratification period and also the depths at which the dissolved oxygen levels begin to drop are established. However, the beginning and ending dates of changes in oxygen levels due to stratification were not captured adequately.

Figure 10 displays RTRM profiles, simulated temperature, and dissolved profiles together for a specific date (July 23, 2013). At this date the AME for temperature was $0.56 \mathrm{C}$ and $1.5 \mathrm{mgO}_{2} / \mathrm{L}$ for dissolved oxygen. Based on the RTRM values the metalimnion began $8 \mathrm{~m}$ below the surface. The temperature and dissolved oxygen profiles also showed correspondingly the commencement of the metalimnion. Below $10 \mathrm{~m}$, RTRM became less than 20 and the hypolimnion began and the profiles tended to flatten as expected.

In both 2013 and 2014, during the stratification periods, the pond volume was occupied by the hypolimnion, metalimnion and epilimnion by $20 \%, 20 \%$ and $60 \%$, respectively as shown in Table 4 . These volumes were calculated with the utilization of the water level - surface area - volume relationships after the determination of the depths of the respective layers using the RTRM values for the days in which observations were carried out.

This volumetric distribution is valid if yearly average volumes are taken into consideration. When the stratification structure was examined, it was observed that the thermal stratification commenced in the spring months with the increase in air temperatures and the hypolimnion zone was relatively larger from May onwards 
(Fig. 12). Then the hypolimnion column decreased and was destroyed with the onset of increasing wind velocities in autumn. In winter, lower temperatures were encountered in the upper layers and higher temperatures at lower layers. A surficial stratification was also observed in the winter months which however was insignificant as RTRM calculations showed.

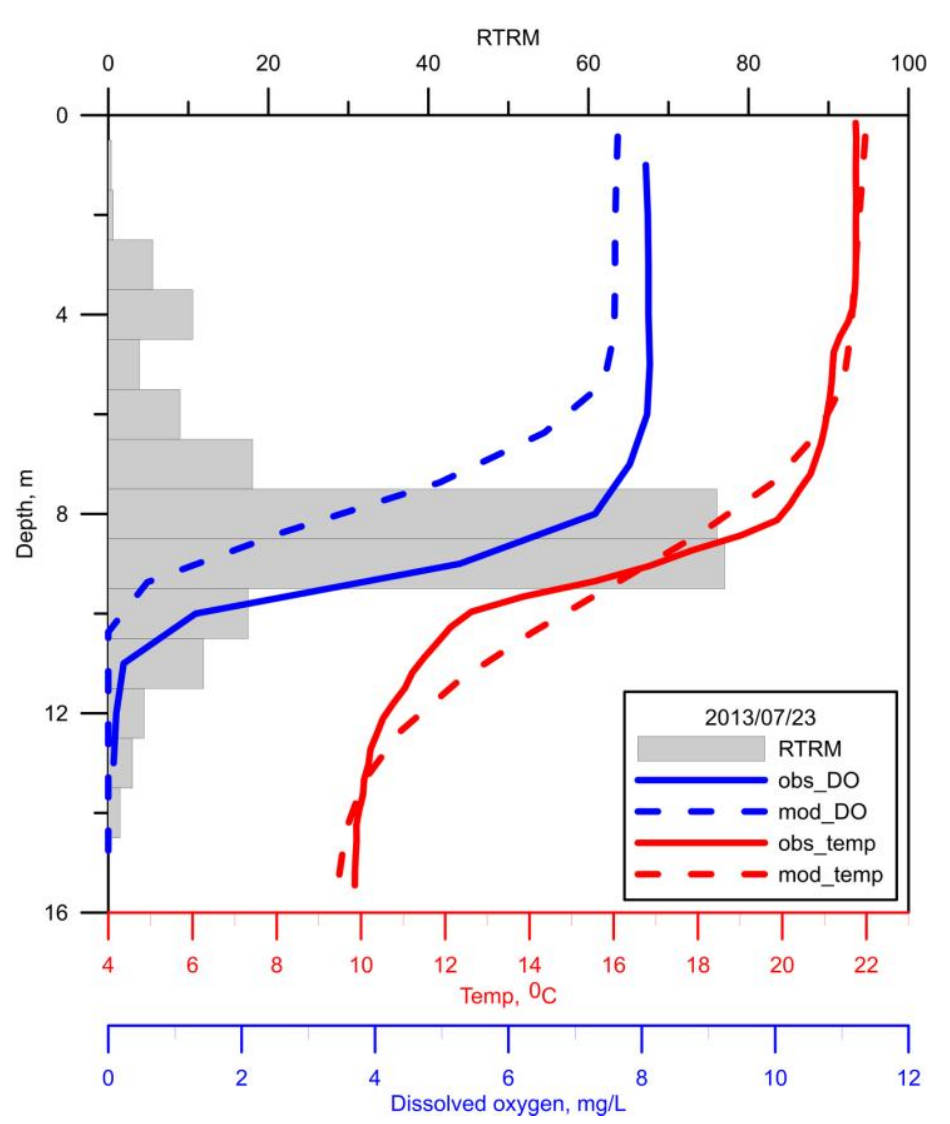

Figure 10. July $23^{\text {th }} 2013$ observation, model and RTRM results

Table 4. Thermal stratification volumes in 2013 and 2014

\begin{tabular}{c|c|c|c|c}
\hline & \multicolumn{2}{|c|}{ Volume of zones } & \multicolumn{2}{c}{ Percentage of zones } \\
\hline & $\mathbf{2 0 1 3}$ & $\mathbf{2 0 1 4}$ & $\mathbf{2 0 1 3}$ & $\mathbf{2 0 1 4}$ \\
\hline Epilimnion, $\mathrm{m}^{3}$ & 697226 & 645403 & 55 & 61 \\
\hline Metalimnion, $\mathrm{m}^{3}$ & 311529 & 234742 & 24 & 23 \\
\hline Hypolimnion, $\mathrm{m}^{3}$ & 270180 & 162288 & 21 & 16 \\
\hline TOTAL, $\mathrm{m}^{3}$ & 1278935 & 1046434 & 100 & 100 \\
\hline
\end{tabular}

\section{Scenarios}

Six scenarios were created to determine how the volume of the pond will change in the future in response to irrigation practice changes. Consequently CE-QUAL-W2 was used to predict the response of temperature to these volume changes. 
The Borabey Pond outlet flow changes in accordance to changes in the use of the water downstream. The fields below the dam outlet are sprinkler irrigated. In the scenarios created, an alternative drip irrigation method was implemented. Shifting from spray to drip irrigation leads to an average of $50 \%$ reduction in irrigation volumes (Güngör and Göncü, 2013). This amount of reduction was incorporated into the scenarios for drip irrigation.

The inflow into the pond changes according to meteorological forcing and seasonal variations. Another factor is the derivation of upstream water to the nearby Keskin Pond. In the scenarios, the input volumes into the pond change according to whether the year is wet or dry. It was observed before, that there was much less inflow in 2014 compared to 2013. Thus 2014 was considered a dry year and 2013 a wet year. Wet (W) and Dry (D) year sequences were created using the input volumes in the corresponding 2013 and 2014 years.

Table 5 displays the scenarios with the corresponding season types (W, D) and irrigation practices (Spr. for sprinkler irrigation and Drp. for drip irrigation).

Table 5. Scenarios

\begin{tabular}{|c|c|c|c|c|c|c|c|c|}
\hline \multirow{2}{*}{ Scenario 1} & \multicolumn{8}{|c|}{ Years } \\
\hline & 2013 & 2014 & 2015 & 2016 & 2017 & 2018 & 2019 & 2020 \\
\hline Season type & $\mathrm{W}$ & $\mathrm{D}$ & $\mathrm{D}$ & $\mathrm{D}$ & $\mathrm{D}$ & $\mathrm{D}$ & $\mathrm{D}$ & $\mathrm{D}$ \\
\hline Irrigation method & Spr. & Spr. & Spr. & Spr. & Spr. & Spr. & Spr. & Spr. \\
\hline \multirow{2}{*}{ Scenario 2} & \multicolumn{8}{|c|}{ Years } \\
\hline & 2013 & 2014 & 2015 & 2016 & 2017 & 2018 & 2019 & 2020 \\
\hline Season type & $\mathrm{W}$ & $\mathrm{D}$ & $\mathrm{D}$ & $\mathrm{D}$ & $\mathrm{D}$ & $\mathrm{D}$ & $\mathrm{D}$ & $\mathrm{D}$ \\
\hline Irrigation method & Spr. & Spr. & Drp. & Drp. & Drp. & Drp. & Drp. & Drp. \\
\hline \multirow{2}{*}{ Scenario 3} & \multicolumn{8}{|c|}{ Years } \\
\hline & 2013 & 2014 & 2015 & 2016 & 2017 & 2018 & 2019 & 2020 \\
\hline Season type & $\mathrm{W}$ & $\mathrm{D}$ & $\mathrm{W}$ & $\mathrm{W}$ & $\mathrm{W}$ & $\mathrm{W}$ & $\mathrm{W}$ & $\mathrm{W}$ \\
\hline Irrigation method & Spr. & Spr. & Spr. & Spr. & Spr. & Spr. & Spr. & Spr. \\
\hline \multirow{2}{*}{ Scenario 4} & \multicolumn{8}{|c|}{ Years } \\
\hline & 2013 & 2014 & 2015 & 2016 & 2017 & 2018 & 2019 & 2020 \\
\hline Season type & $\mathrm{W}$ & $\mathrm{D}$ & $\mathrm{W}$ & $\mathrm{D}$ & $\mathrm{W}$ & $\mathrm{D}$ & $\mathrm{W}$ & $\mathrm{D}$ \\
\hline Irrigation method & Spr. & Spr. & Spr. & Spr. & Spr. & Spr. & Spr. & Spr. \\
\hline \multirow{2}{*}{ Scenario 5} & \multicolumn{8}{|c|}{ Years } \\
\hline & 2013 & 2014 & 2015 & 2016 & 2017 & 2018 & 2019 & 2020 \\
\hline Season type & $\mathrm{W}$ & $\mathrm{D}$ & $\mathrm{W}$ & $\mathrm{D}$ & $\mathrm{W}$ & $\mathrm{D}$ & $\mathrm{W}$ & $\mathrm{D}$ \\
\hline Irrigation method & Spr. & Spr. & Drp. & Drp. & Drp. & Drp. & Drp. & Drp. \\
\hline \multirow{2}{*}{ Scenario 6} & \multicolumn{8}{|c|}{ Years } \\
\hline & 2013 & 2014 & 2015 & 2016 & 2017 & 2018 & 2019 & 2020 \\
\hline Season type & $\mathrm{W}$ & $\mathrm{D}$ & $\mathrm{W}$ & $\mathrm{W}$ & $\mathrm{W}$ & $\mathrm{W}$ & $\mathrm{W}$ & $\mathrm{W}$ \\
\hline Irrigation method & Spr. & Spr. & Drp. & Drp. & Drp. & Drp. & Drp. & Drp. \\
\hline
\end{tabular}

The model was implemented for each scenario with the inputs as given in Table 5 and run from 2014 to 2020 . Figure 11 displays how the pond volume changed with respect to scenarios. 


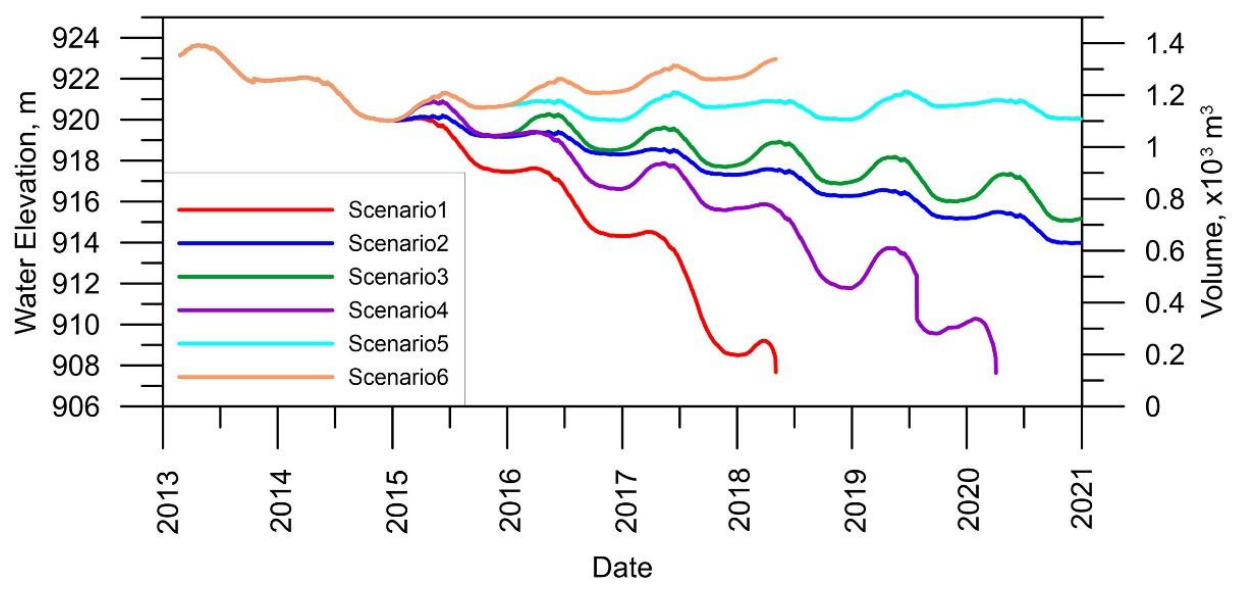

Figure 11. Pond volume and water level change with respect to scenarios

With the exception of scenarios 5 and 6 , decreases in pond volumes were observed. Only scenario 6 predicted increases in pond volume. Scenario 6 combined wet perios with drip irrigation which led to water savings over a large volume. For scenarios 1 and 4 which combine sprinkler irrigation with dry periods/wet-dry sequences the pond became almost dry.

Table 6 presents the outlet temperature changes in the pond according to scenarios. For every scenario except the last one, temperature increases were predicted. Figure 12 displays the evolution of temperature for every scenario and corresponding linear trends.

Table 6. Outlet water temperature according to scenarios

\begin{tabular}{c|c|c}
\hline Scenarios & $\begin{array}{c}\text { Total temperature change } \\
\left({ }^{\circ} \mathbf{C} \text { in years }\right.\end{array}$ & $\begin{array}{c}\text { Temperature change } \\
\left({ }^{\circ} \mathbf{C}\right) / \text { year }\end{array}$ \\
\hline 1 & $5.34^{\circ} \mathrm{C}$ in 4.9 years & 1.08 \\
\hline 2 & $6.05^{\circ} \mathrm{C}$ in 7.9 years & 0.86 \\
\hline 3 & $5.35^{\circ} \mathrm{C}$ in 7.9 years & 0.68 \\
\hline 4 & $3.34^{\circ} \mathrm{C}$ in 7.1 years & 0.47 \\
\hline 5 & $0.21^{\circ} \mathrm{C}$ in 7.8 years & 0.03 \\
\hline 6 & $-2.18^{\circ} \mathrm{C}$ in 5.2 years & -0.42 \\
\hline
\end{tabular}

The model simulations showed that the stratification pattern changed with decreasing pond volume. In the first scenario, temperature fluctuations change from a range of 4$14{ }^{\circ} \mathrm{C}$ to a range of $4-23{ }^{\circ} \mathrm{C}$. The linear change was observed as $0.82{ }^{\circ} \mathrm{C} /$ year. As the stratification pattern was destroyed due to decreasing volume, the pond temperature became more affected by atmospheric conditions. The same was observed for scenario 4 , especially when the water depth dropped to around $7 \mathrm{~m}$.

On the other hand, though the periodic fluctuation range showed increases, scenarios 2 and 3 did not show the effects of atmospheric influences as the water depth did not fall below $7 \mathrm{~m}$. In scenario 5, there was a very small linear trend and the fluctuation range did not change with time. In the last scenario, the water temperatures dropped and the fluctuation range decreased in accordance with volume increases. 
These findings imply that, if it is planned to obtain benefits from the Borabey Pond for future years, the water withdrawals need to be reduced. Effective reductions can be achieved by shifting to drip irrigation practices. However, even this may not be sufficient to maintain desired water levels (Scenario 2). The transfer of water from the Borabey watershed to the Keskin Pond must be stopped, at least for some months in a dry year. Otherwise, a dry-up period of the pond in a dry weather sequence seems in inevitable.

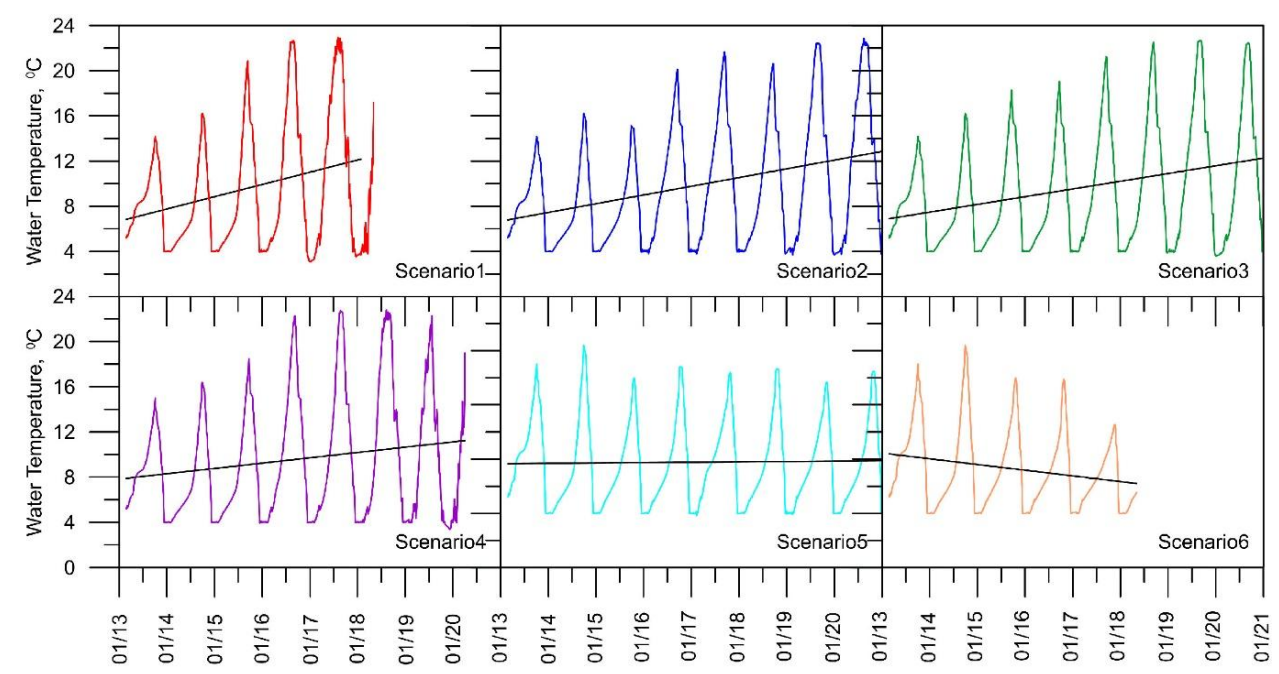

Figure 12. Evolution of temperature for every scenario and corresponding linear trends

\section{Conclusions and recommendations}

In this modeling study, some problems were encountered which are prone to affect model results. The input and output flows were not measured, but estimated based on assumptions. This created uncertainties on the primary model inputs. The input and output volumes which were estimated can also be more accurately found out using a comprehensive watershed model. When such less biased results become available in the future, the accuracy of this study can be assessed by changing the relevant pond input and output values. Moreover, long-term constituent concentrations in the quality constituents other than dissolved oxygen averages of observations were utilized for the inflow concentrations and initial pond concentrations. These concentrations, especially those that affect the oxygen depletion dynamics, need to be monitored more closely.

In the simulation of water temperature, the constituent concentrations affect the absorption of light with depth and directly influence the light extinction coefficient (EXH2O). If constituent concentrations cannot be adequately modeled due to uncertainties in the inputs, the light extinction coefficient will show uncertainties, to which will increase errors in the temperature simulations. In order to reduce errors due to constituent concentrations the absorption coefficients due to inorganic suspended solids (EXSS), organic suspended solids (EXOM) and algae (EXA) were set to zero and the light extinction coefficient was made depended only on water absorption of light.

The AME in temperature simulation was observed to be $0.77{ }^{\circ} \mathrm{C}$ if the light extinction coefficient was only dependent on water absorption, but to rise to $1.12{ }^{\circ} \mathrm{C}$ when the effects of the water quality constituents were taken into account. This stresses 
the importance of correctly representing the amounts of constituents related to carbon and of algae and protozoa in the water body.

In the modeling of the dissolved oxygen levels, all the mathematical relationships about the reaeration process were examined and it was found out that the different relationships created different AME values. During the calibration period the AME changed between 1.018 and $1.298 \mathrm{mg} / \mathrm{L}$ due to the different relationships. This shows that the different mathematical formulations simulate the real world differently and this fact should be taken into account during the modeling. More studies about the applicability of a particular formulation to a particular environmental setting are needed for better modeling of the behavior of dissolved oxygen during stratification.

Acknowledgements. The authors thank to Anadolu University, Scientific Research Project Funding (AU BAP) for their financial support [Project number: 1208F129].

\section{REFERENCES}

[1] Alpaslan, K., Sesli, A., Tepe, R., Ozbey, N., Birici, N., Seker, T., Kocer, M. A. T. (2012): Vertical and seasonal changes of water quality in Keban Dam Reservoir. - Journal of FisheriesSciences.com 6(3): 252-262.

[2] Babajimopoulos, C., Papadopoulos, F. (1986): Mathematical prediction of thermal stratification of Lake Ostrovo (Vegoritis), Greece. - Water Resources Research 22(11): 1590-1596.

[3] Batick, B. M. (2011): Modeling Temperature and Dissolved Oxygen in the Cheatham Reservoir with CE-QUAL-W2. - Unpublished MSc Thesis, Vanderbilt University, Nashville.

[4] Becker, V., Huszar, V. L. M., Crossetti, L. O. (2009): Responses of phytoplankton functional groups to the mixing regime in a deep subtropical reservoir. - Hydrobiologia 628(1): 137-151.

[5] Bell, V. A., George, D. G., Moore, R. J., Parker, J. (2006): Using a 1-D mixing model to simulate the vertical flux of heat and oxygen in a lake subject to episodic mixing. Ecological Modelling 190(1-2): 41-54.

[6] Berger, C. J., Wells, S. A., Annear, R., (2005): Laurence Lake Temperature Model. Maseeh College of Engineering and Computer Science Department of Civil and Environmental Engineering, Portland State University, Portland, Oregon.

[7] Birge, E. (1910): An unregarded factor in lakes temperatures. - Trans. Wis. Acad. Sci. Arts Lett 16: 989-1004.

[8] Bocaniov, S. A., Ullmann, C., Rinke, K., Lamb, K. G., Boehrer, B. (2014): Internal waves and mixing in a stratified reservoir: Insights from three-dimensional modeling. Limnologica - Ecology and Management of Inland Waters 49: 52-67.

[9] Bonalumi, M., Anselmetti, F. S., Wuest, A., Schmid, M. (2012): Modeling of temperature and turbidity in a natural lake and a reservoir connected by pumped-storage operations. Water Resources Research 48: 1-18.

[10] Bonnet, M. P., Poulin, M. (2004): DyLEM-1D: a 1D physical and biochemical model for planktonic succession, nutrients and dissolved oxygen cycling: Application to a hypereutrophic reservoir. - Ecological Modelling 180(2): 317-344.

[11] Bowen, J. D., Hieronymus, J. W. (2003): A CE-QUAL-W2 model of Neuse Estuary for total maximum daily load development. - Journal of Water Resources Planning and Management-Asce 129(4): 283-294.

[12] Branco, B. F., Torgersen, T. (2009): Predicting the onset of thermal stratification in shallow inland waterbodies. - Aquatic Sciences 71(1): 65-79. 
[13] Branco, C. W. C., Kozlowsky-Suzuki, B., Sousa-Filho, I. F., Guarino, A. W. S., Rocha, R. J. (2009): Impact of climate on the vertical water column structure of Lajes Reservoir (Brazil): A tropical reservoir case. - Lakes \& Reservoirs: Research \& Management 14(3): 175-191.

[14] Caliskan, A., Elci, S. (2009): Effects of selective withdrawal on hydrodynamics of a stratified reservoir. - Water Resources Management 23(7): 1257-1273.

[15] Chapman, L. J., Chapman, C. A., Crisman, T. L., Nordlie, F. G. (1998): Dissolved oxygen and thermal regimes of a Ugandan crater lake. - Hydrobiologia 385: 201-211.

[16] Chapra, S. C. (1997): Surface Water-Quality Modeling. - McGraw-Hill, New York.

[17] Chimney, M. J., Wenkert, L., Pietro, K. C. (2006): Patterns of vertical stratification in a subtropical constructed wetland in south Florida (USA). - Ecological Engineering 27(4): 322-330.

[18] Churchill, J. H., Kerfoot, W. C. (2007): The impact of surface heat flux and wind on thermal stratification in Portage Lake, Michigan. - Journal of Great Lakes Research 33(1): 143-155.

[19] Colarusso, L. A., Chermak, J. A., Priscu, J. C., Miller, F. K. (2003): Modeling pit lake water column stability using Ce-Qual-W2. - Tailings and Mine Waste 03: 213-222.

[20] Cole, T. M. (2000): Reservoir thermal modeling using CE-QUAL-W2. - Development and Application of Computer Techniques to Environmental Studies VII(4): 237-246.

[21] Cole, T. M., Tillman, D. H., (1999): Water Quality Modeling of Lake Monroe Using CEQUAL-W2. - US Army Corps of Engineers Waterways Experiment Station, Louisville.

[22] Cole, T. M., Wells, S. A. (2013): CE-QUAL-W2: A two-dimensional, laterally averaged, hydrodynamic and water quality model, version 3.7. - Unpublished Thesis, Portland State University, Portland.

[23] Dayyani, S., Mohammadi, K., Najib, H. R. (2003): River flow estimation for ungauged stations using GIS model. - Seventh International Water Technology Conference Egypt 1-3 April 2003.

[24] Deliman, P. N., Gerald, J. A. (2002): Application of the two-dimensional hydrothermal and water quality model, CE-QUAL-W2, to the Chesapeake Bay - Conowingo Reservoir. - Lake and Reservoir Management 18(1): 10-19.

[25] Devonis, C. S. (2011): Wachusett Reservoir Contaminant Spill Modeling Using CEQUAL W2. - Unpublished Thesis, University of Massachusetts, Amherst.

[26] Diogo, P. A., Fonseca, M., Coelho, P. S., Mateus, N. S., Almeida, M. C., Rodrigues, A. C. (2008): Reservoir phosphorous sources evaluation and water quality modeling in a transboundary watershed. - Desalination 226(1-3): 200-214.

[27] Dueri, S., Castro-Jimenez, J., Zaldivar, J. M. (2009): Modelling the influence of thermal stratification and complete mixing on the distribution and fluxes of polychlorinated biphenyls in the water column of Ispra Bay (Lake Maggiore). - Chemosphere 75(9): 1266-72.

[28] Elci, S. (2008): Effects of thermal stratification and mixing on reservoir water quality. Limnology 9(2): 135-142.

[29] Erturk, A., Ekdal, A., Gurel, M., Zorlutuna, Y., Tavsan, C., Seker, D. Z., Tanik, A., Ozturk, I. (2008): Application of Water Quality Modelling as a Decision Support System Tool for Planned Buyuk Melen Reservoir and its Watershed. - In: Gönenç, I. E., Vadineanu, A., Wolflin, J. P., Russo, R. C. (eds.) Sustainable Use and Development of Watersheds. Springer, Dordrecht.

[30] Göncü, S., Avdan, U., Yiğit Avdan, Z., Albek, E., (2014): Monitoring the Porsuk Reservoir Dissolved Oxygen Concentration Based on Stratification and Investigation of a Suitable Hypolimnetic Aeration Method Intended to Increase the Lake Assimilation Capacity. - 1208F129, Eskisehir-TURKEY, Anadolu University Research Project.

[31] Gunduz, O., Soyupak, S., Yurteri, C. (1998): Development of water quality management strategies for the proposed Isikli reservoir. - Water Science and Technology 37(2): 369376. 
[32] Güngör, Ö., Göncü, S. (2013): Application of the soil and water assessment tool model on the Lower Porsuk Stream Watershed. - Hydrological Processes 27(3): 453-466.

[33] Ha, S. R., Lee, J. Y. (2007): Application of CE-QUAL-W2 Model to Eutrophication Simulation in Daecheong Reservoir Stratified by Turbidity Storms. - In: Sengupta, M., Dalwani, R. (eds.) Proceedings of Taal2007: The 12th World Lake Conference, Jaipur, India.

[34] Hasanoğlu, E. (2012): Investigation of Thermal Stratification Structure and Dissolved Oxygen Profiles in Borabey Pond. - Unpublished MSc Thesis, Anadolu University, Eskişehir.

[35] Hassan, H., Aramaki, T., Hanaki, K., Matsuo, T., Wilby, R. (1998): Lake stratification and temperature profiles simulated using downscaled GCM output. - Water Science and Technology 38(11): 217-226.

[36] Hudson, J. J., Vandergucht, D. M. (2015): Spatial and temporal patterns in physical properties and dissolved oxygen in Lake Diefenbaker, a large reservoir on the Canadian Prairies. - Journal of Great Lakes Research 41: 22-33.

[37] Kaya, M. (2013): Interaction of Water Quality with Basin Components in Small Water Bodies. - Unpublished MSc Thesis, Anadolu University, Eskişehir.

[38] Kerimoglu, O., Rinke, K. (2013): Stratification dynamics in a shallow reservoir under different hydro-meteorological scenarios and operational strategies. - Water Resources Research 49: 7518-7527.

[39] Kim, Y., Kim, B. (2006): Application of a 2-dimensional water quality model (CEQUAL-W2) to the turbidity interflow in a deep reservoir (Lake Soyang, Korea). - Lake and Reservoir Management 22(3): 213-222.

[40] Kindle, E. M. (1929): A Comparative study of different types of thermal stratification in lakes and their influence on the formation of Marl. - The Journal of Geology 37(2): 150157.

[41] Kortmann, R. W., Henry, D. D., Kuether, A., Kaufman, S. (1982): Epilimnetic nutrient loading by metalimnetic erosion and resultant algal responses in Lake Waramaug, Connecticut. - Hydrobiologia 91(1): 501-510.

[42] Kuo, J. T., Lung, W. S., Yang, C. P., Liu, W. C., Yang, M. D., Tang, T. S. (2006): Eutrophication modelling of reservoirs in Taiwan. - Environmental Modelling \& Software 21(6): 829-844.

[43] Lap, B. Q., Tuan, N. V., Hamagami, K., Iguchi, S., Mori, K., Hirai, Y. (2009): Formation and disappearance of thermal stratification in a small shallow lake. - Journal of the Faculty of Agriculture Kyushu University 54(1): 251-259.

[44] Li, Y. P., Acharya, K., Chen, D., Stone, M. (2010): Modeling water ages and thermal structure of Lake Mead under changing water levels. - Lake and Reservoir Management 26(4): 258-272.

[45] Lindim, C., Pinho, J. L., Vieira, J. M. P. (2011): Analysis of spatial and temporal patterns in a large reservoir using water quality and hydrodynamic modeling. - Ecological Modelling 222(14): 2485-2494.

[46] Rice, D. A., Tsay, T. K., Effler, S. W., Driscoll, C. T. (1989): Modeling thermal stratification in transparent Adirondack Lake. - Journal of Water Resources Planning and Management-Asce 115(4): 440-456.

[47] Salonen, K., Sarvala, J., Jarvinen, M., Langenberg, V., Nuottajarvi, M., Vuorio, K., Chitamwebwa, D. B. R. (1999): Phytoplankton in Lake Tanganyika - vertical and horizontal distribution of in vivo fluorescence. - Hydrobiologia 407: 89-103.

[48] Song, K., Xenopoulos, M. A., Buttle, J. M., Marsalek, J., Wagner, N. D., Pick, F. R., Frost, P. C. (2013): Thermal stratification patterns in urban ponds and their relationships with vertical nutrient gradients. - J Environ Manag 127: 317-323.

[49] Spigel, R. H., Howard-Williams, C., Gibbs, M., Stephens, S., Waugh, B. (2005): Field calibration of a formula for entrance mixing of river inflows to lakes: Lake Taupo, North 
Island, New Zealand. - New Zealand Journal of Marine and Freshwater Research 39(4): 785-802.

[50] Stansbury, J., Kozimor, L., Admiraal, D., Dove, E. (2008): Water quality modeling of the effects of macrophytes on dissolved oxygen in a shallow tailwater reservoir. - Lake and Reservoir Management 24(4): 339-348.

[51] Williams, N. T. (2007): Modeling Dissolved Oxygen in Lake Powell. - Unpublished Thesis, Brigham Young University, Provo, UT.

[52] Zhang, H., Culver, D. A., Boegman, L. (2008): A two-dimensional ecological model of Lake Erie: Application to estimate dreissenid impacts on large lake plankton populations. - Ecological Modelling 214(2-4): 219-241.

[53] Zhang, Y., Wu, Z., Liu, M., He, J., Shi, K., Zhou, Y., Wang, M., Liu, X. (2015): Dissolved oxygen stratification and response to thermal structure and long-term climate change in a large and deep subtropical reservoir (Lake Qiandaohu, China). - Water Research 75: 249-258. 